\title{
Effects of water pH on gamete activation, embryonic development, and larval normality in Prochilodus lineatus
}

\author{
Efeitos do pH da água na ativação dos gametas, desenvolvimento \\ embrionário e normalidade larval no Prochilodus lineatus
}

\author{
Eduardo Antônio Sanches ${ }^{1}$; Giovano Neumann²; César Pereira Rebechi de Toledo²; \\ Robie Allan Bombardelli ${ }^{3}$
}

\begin{abstract}
We investigated the effects of breeding water $\mathrm{pH}$ on the spermatic motility, artificial fertilization, and initial development of offspring in curimba, Prochilodus lineatus. After hormonal induction, we conducted gamete activation, artificial fertilization, and embryo incubation in water with $\mathrm{pH}$ values of $4.43 \pm 0.13,5.82 \pm 0.14,7.37 \pm 0.10,8.21 \pm 0.06$, and $9.57 \pm 0.16$. When the water $\mathrm{pH}$ was 6.65 , spermatic motility was maintained for $\leq 25.21 \mathrm{~s}(\mathrm{P}<0.05)$. The highest fertilization rates $(\mathrm{P}<0.05)$ were obtained when the water $\mathrm{pH}$ ranged from $5.82 \pm 0.14$ to $8.21 \pm 0.06$, and the highest hatching rates $(\mathrm{P}<$ $0.05)$ were observed when the water $\mathrm{pH}$ was $7.37 \pm 0.10$. A water $\mathrm{pH}$ of between $7.37 \pm 0.10$ and 8.21 \pm 0.06 resulted in more complete formation of the perivitelline space $(\mathrm{P}<0.05)$; additionally, embryos incubated in alkaline waters produced a higher percentage of normal larvae $(\mathrm{P}<0.05)$, despite increased mortality levels. Our results indicate that the $\mathrm{pH}$ of the water used for gamete activation, artificial oocyte fertilization, and incubation of eggs and larvae of $P$. lineatus should be $\sim 7$, in order to promote successful breeding and normal larval production.
\end{abstract}

Key words: Artificial reproduction, curimba, fertilization, fish, sperm motility, water $\mathrm{pH}$

\section{Resumo}

Foram investigados os efeitos do $\mathrm{pH}$ da água de criação na motilidade espermática, fertilização artificial, e no desenvolvimento inicial da prole de curimba, Prochilodus lineatus. Após a indução hormonal, realizamos a ativação dos gametas, fecundação artificial e incubação dos embriões em água com os valores de $\mathrm{pH}$ de $4,43 \pm 0,13,5,82 \pm 0,14,7,37 \pm 0,10,8,21 \pm 0,06$ e 9,57 $\pm 0,16$. Quando o $\mathrm{pH}$ da água foi de 6,65, a motilidade espermática foi mantida em $\leq 25.21 \mathrm{~s}(\mathrm{P}<0,05)$. As maiores taxas de fertilização $(\mathrm{P}<0,05)$ foram obtidas quando o $\mathrm{pH}$ da água variou de 5,82 $\pm 0,14$ a $8,21 \pm 0,06$, e as maiores taxas de eclosão $(\mathrm{P}<0,05)$ foram observadas quando o $\mathrm{pH}$ da água foi de 7,37 $\pm 0,10$. O pH da água entre 7,37 \pm 0,10 e $8,21 \pm 0,06$ resultou na formação mais completa do espaço perivitelino $(\mathrm{P}<0,05)$; Além disso, os embriões incubados em águas alcalinas tiveram maior porcentagem de larvas normal $(\mathrm{P}<0,05)$, apesar do aumento dos níveis de mortalidade. Os nossos resultados indicam que o $\mathrm{pH}$ da água utilizada para a ativação dos gametas, a fertilização artificial do ovócitos, e de incubação dos ovos e larvas de $P$. lineatus deve ser $\sim 7$, a fim de promover a criação e produção bem sucedida de animais e de larvas normais.

Palavras-chave: Reprodução artificial, curimba, fertilização, peixe, motilidade espermática, $\mathrm{pH}$ da água

\footnotetext{
${ }^{1}$ Prof. Dr. Adjunto em Aquicultura, Universidade Estadual de São Paulo, UNESP, Registro, SP, Brasil. E-mail: sanches@registro. unesp.br

${ }^{2}$ Mestres em Recursos Pesqueiros e Engenharia de Pesca, Discente da Universidade Estadual do Oeste do Paraná, UNIOESTE, Toledo, PR, Brasil. E-mail: giovanoneumann@hotmail.com; cprtoledo@gmail.com

3 Prof. Dr. Adjunto em Zootecnia, UNIOESTE, Toledo, PR, Brasil. E-mail: rabombardelli@gmail.com

* Author for correspondence
} 


\section{Introduction}

The curimba, Prochilodus lineatus, is a fish belonging to the order Characiformes, family Prochilodontidae and is widespread through the Paraná and Paraguay River basins (NAKATANI et al., 2001). The species is important in aquatic ecosystems because of its major roles in trophic chains (PEREIRA et al., 2004) and fisheries (NOVAES; CARVALHO, 2009). Additionally, on the basis of its wide reproductive migrations (PEREIRA et al., 2009), high fecundity (MENEZES; VAZZOLER, 1992), and ability to tolerate several manipulation levels, the curimba is considered as a good model for breeding studies of rheophilic fish.

When $P$. lineatus is kept in captivity, its reproductive cycle is interrupted (MORAES et al., 2004); hence, hormonal manipulation is required to induce the final gonadal maturation and the release of gametes for further artificial fertilization (WOYNAROVICH; HORVÁTH, 1983). During artificial reproduction, the gametes and embryos exposed to water are susceptible to abiotic features (JONES; REYNOLDS, 1997; KIME; NASH, 1999). Changes in the water $\mathrm{pH}$ may cause damage to aquatic organisms (TOMITA; BEYRUTH, 2002).

In general, aquaculture procedures should be conducted in water with $\mathrm{pH}$ values of 6.0-9.0, in order to avoid causing stress and mortality (OBA et al., 2009) in juveniles and adults. The harmful effects of water $\mathrm{pH}$ may result from a direct influence on animal physiology (LOPES et al., 2001), or an indirect influence by making available toxic $\mathrm{NH}_{3}$ (PEREIRA; MERCANTE, 2005). Moreover, water $\mathrm{pH}$ affects the quality and viability of spermatozoa (LAHNSTEINER et al., 2004; ALAVI; COSSON, 2005), embryos, and larvae (FERREIRA et al., 2001, LOPES et al., 2001; ZANIBONI-FILHO et al., 2009), thereby limiting the success of artificial breeding, or even hindering the natural propagation of populations in contaminated environments.

In the present study, we investigated the effects of breeding water $\mathrm{pH}$ on the spermatic motility, artificial fertilization, and initial offspring development in curimba, $P$. lineatus.

\section{Materials and Methods}

We conducted our experiment in the Laboratory of Breeding Technology of Aquatic Organisms (Latraac), at the Institute of Environmental Aquaculture Research (Inpaa), State University of West Paraná (Unioeste), Toledo, Paraná, Brazil.

We selected $14 P$. lineatus breeders. Prior to the assay, the fish were kept in a $200-\mathrm{m}^{2}$ earthen pond without water exchange, except for the replacement of water lost through evaporation and infiltration. The specimens were fed with a diet of extruded commercial food containing $32 \%$ crude protein.

During the breeding season, we selected 7 females $(656.8 \pm 26.9 \mathrm{~g})$ and 7 males $(510.0 \pm 101.1$ g) showing signs of final gonadal maturation. The females had round and soft bellies, with pinky and evident urogenital papilla; the males released sperm after slight coelomatic pressure. After collection, the specimens were individually weighed, tagged, and separated according to gender, into 2 aerated tanks with constant water flow. Females were hormonally induced via 2 intramuscular applications of carp pituitary extract (CPE); firstly, $0.5 \mathrm{mg} \mathrm{kg}^{-1}$, and secondly (12 h later), $5.0 \mathrm{mg} \mathrm{kg}^{-1}$. Males were injected with a single $3.0 \mathrm{mg} \mathrm{kg}^{-1}$ dose of CPE.

At 160 degree-hours (6 h 24 min; water temperature of $25^{\circ} \mathrm{C}$ ) after the second hormonal application, we collected semen samples from the males. Mature males were dried by using fabric and paper tissues, and coelomatic massage was performed from head to tail. The first semen drops were discarded to avoid possible contamination with urine or feces; the remaining semen $(1.6 \pm 1.1 \mathrm{~mL})$ was collected in disposable syringes $(3.0 \pm 0.1 \mathrm{~mL})$. The semen samples from each breeder were mixed to form a seminal pool, which was maintained at a cool temperature $\left(15^{\circ} \mathrm{C}\right)$ during the breeding procedure and spermatic analyses (ROMAGOSA 
et al., 2010). We analyzed semen samples from this pool. The spermatozoa concentration was determined by using cell counting in a Neubauer chamber (SANCHES et al., 2011); the membrane integrity was evaluated by using Eosin-Nigrosin staining (adapted from BLOM, 1950); and the duration of spermatic motility was determined by measuring the time interval from the start of spermatic activity until $<50 \%$ of spermatozoa remained motile (SANCHES et al., 2009).

In addition, we performed oocyte collection at 160 degree-hours after the second hormonal application, by using coelomatic massage from head to tail. We selected gametes from 5 females, to form a pool of oocytes based on homogeneous color and size. We subsequently obtained a minimum of $30.1-\mathrm{mL}$ oocytes samples, in order to estimate the number of oocytes per $\mathrm{mL}$ and thus evaluate the female fecundity.

We conducted the fertilization assay and egg incubation in water at 5 different $\mathrm{pH}$ values, following a completely randomized experimental design composed of 5 treatments and 4 replicates. The water $\mathrm{pH}$ values were adjusted $12 \mathrm{~h}$ before the start the experiment, to 4.0, 5.0, 7.0, 8.5, and 10.0 , by adding $\mathrm{HCl}\left(\right.$ Biotec $^{\circledR}$ ) or $0.2 \mathrm{M} \mathrm{NaOH}$ solution $\left(\right.$ Vetec $\left.^{\circledR}\right)$ in a non-buffered medium. In each experimental unit, we measured the water $\mathrm{pH}$ at 4-h intervals up to hatching, by using a digital $\mathrm{pH}$ meter (Tecnal ${ }^{\circledR}$ Tec 5); we used the average results to determine the experimental treatments (4.43 \pm $0.13,5.82 \pm 0.14,7.37 \pm 0.10,8.21 \pm 0.06$, and 9.57 $\pm 0.16)$. We considered a 2.5 -L conical incubator containing $2.0 \mathrm{~mL}$ of oocytes (i.e., $2507 \pm 41$ oocytes) as an experimental unit. For each treatment, the 4 replicates (incubators) were individually placed in 5 different experimental recirculation systems, each containing $300 \mathrm{~L}$ of water. We monitored the temperature, dissolved oxygen $\left(\mathrm{YSI}^{\circledR} 550^{\mathrm{a}}\right.$ ), and electric conductivity (Digimed DM-3P) of the water at 8 -h intervals, from fertilization to hatching.

The artificial fertilization procedure was performed by using a dry method with $150-\mathrm{mL}$ plastic recipients (WITECK et al., 2011); 100 $\mu \mathrm{L}$ of semen were added to $2 \mathrm{~mL}$ of oocytes, i.e., corresponding to $1.13 \times 10^{6}$ spermatozoa per oocyte (SOUZA, 2007). After gamete mixing, $20 \mathrm{~mL}$ of water from each of the incubation systems were added and mixed for $60 \mathrm{~s}$. Finally, the oocytes were washed 3 times with the same water and incubated.

We measured the fertilization rates $8 \mathrm{~h}$ after fertilization (blastopore closure stage) (NINHAUSSILVEIRA et al., 2006), by counting approximately 300 eggs $(2 \mathrm{~mL})$ in each experimental unit (HILBIG et al., 2008). During sampling, the differences in egg size in each incubator were observed by counting the number of eggs contained in $1 \mathrm{~mL}$ of water from each experimental unit. This procedure was performed to estimate the diameter of the incubated eggs, based on the fact that samples with a high number of eggs per $\mathrm{mL}$ contained eggs with small diameters and vice versa. After hatching, all of the larvae from each experimental unit were fixed in $4 \%$ buffered formaldehyde solution and counted, to estimate the rate of egg hatching and percentage of normal larvae. Larval normality was analyzed under a stereomicroscope $(10 \times)$ by evaluating 200 larvae from each experimental unit. Normal larvae were considered as those that showed no morphological alterations in the backbone, yolk sac, or head (FRAYSSE et al., 2006; JEZIERSKA et al., 2009).

Immediately after artificial fertilization, we analyzed a second sperm sample, to determine the duration of spermatic motility (SANCHES et al., 2009); this was considered as the time interval from the start of spermatic activity until $50 \%$ of the spermatozoa remained motile. The experimental design was identical to that mentioned, but the $\mathrm{pH}$ values were adjusted to $4.19,5.49,7.13,8.35$, and 9.89. We used an aliquot of semen sampled from the same sperm pool as that used in the fertilization assay.

We analyzed the data obtained for water electric conductivity, water dissolved oxygen, 
water temperature, fertilization rates, hatching rates, normal larvae rates, and number of eggs per $\mathrm{mL}$, by using analysis of variance (ANOVA) $(\mathrm{P}<0.05)$. When significant effects of treatments were identified, we used Tukey's test $(\mathrm{P}<0.05)$. We analyzed the data obtained for the duration of spermatic motility, by using a non-linear estimation test $\left(y=a x^{b} \exp ^{c x}\right)$ with a probability of $5 \%$. The predicted residual normality and homoscedasticity of variances were checked according to Quinn and Keough (2002). In all of our analyses, we used the software Statistica 7.0 (STATSOFT, 2005).

\section{Results}

The collected semen contained $2.83 \pm 0.21 \times 10^{10}$ spermatozoa per $\mathrm{mL}$ and had $97.30 \pm 0.1 \%$ living spermatozoa. Immediately after semen collection, the duration of spermatic motility in distilled water (pH 7.79) was $24.34 \pm 1.8 \mathrm{~s}$.

The temperature $\left(25.60 \pm 0.29^{\circ} \mathrm{C}\right)$, electric conductivity $\left(0.13 \pm 0.01 \mathrm{mS} \mathrm{cm} \mathrm{cm}^{-1}\right)$, and dissolved oxygen $\left(4.17 \pm 0.16 \mathrm{~L}^{-1}\right)$ of the experimental water remained stable $(\mathrm{P}>0.05)$ from the time of fertilization until the hatching period (Table 1).

Table 1. Physical-chemical parameters of the water used to egg incubation (mean $\pm \mathrm{SD}$ ).

\begin{tabular}{cccc}
\hline $\mathrm{pH}$ & $\mathrm{COND}\left(\mathrm{mS} \mathrm{cm}^{-1}\right)$ & $\mathrm{DO}\left(\mathrm{mg} \mathrm{L}^{-1}\right)$ & TEMP $\left({ }^{\circ} \mathrm{C}\right)$ \\
\hline $4.43 \pm 0.13^{\mathrm{a}}$ & $0.17 \pm 0.00$ & $4.27 \pm 0.42$ & $25.67 \pm 0.73$ \\
$5.82 \pm 0.14^{\mathrm{b}}$ & $0.13 \pm 0.00$ & $4.77 \pm 0.33$ & $26.67 \pm 0.73$ \\
$7.37 \pm 0.10^{\mathrm{c}}$ & $0.11 \pm 0.01$ & $3.70 \pm 0.51$ & $25.50 \pm 0.87$ \\
$8.21 \pm 0.06^{\mathrm{d}}$ & $0.10 \pm 0.00$ & $4.13 \pm 0.03$ & $25.50 \pm 0.87$ \\
$9.57 \pm 0.16^{\mathrm{e}}$ & $0.13 \pm 0.04$ & $3.97 \pm 0.03$ & $25.67 \pm 0.73$ \\
\hline $\mathrm{F}_{(4.15)=} 269.46 ; \mathrm{p}=0.00$ & $\mathrm{~F}_{(4.10)}=1.68 ; \mathrm{p}=0.23$ & $\mathrm{~F}_{(4.10)}=1.44 ; \mathrm{p}=0.29$ & $\mathrm{~F}_{(4.10)}=0.01 ; \mathrm{p}=0.99$ \\
\hline
\end{tabular}

$F, F$ value; P, probability of error in variance analysis; COND, electric conductivity; DO, dissolved oxygen; TEMP, water temperature. Different letters in the same column indicate significant differences according to Tukey's test $(\mathrm{P}<0.05)$.

The water $\mathrm{pH}$ influenced the duration of spermatic motility $(\mathrm{P}<0.05)$ in a non-linear manner (Figure 1). Semen dilution in water with a $\mathrm{pH}$ of 6.65 showed the highest theoretical duration of spermatic motility (25.11 s).

The water $\mathrm{pH}$ affected $(\mathrm{P}<0.05)$ the fertilization rates (Figure 2), as well as the egg hydration process and therefore the egg size (Figure 3 ). The highest fertilization rates were obtained when the water $\mathrm{pH}$ ranged from $5.82 \pm 0.14$ to $8.21 \pm 0.06$ (Figure 2). On the other hand, when the water $\mathrm{pH}$ varied from $7.37 \pm 0.10$ to $8.21 \pm 0.06$, we recorded a lower number of eggs per $\mathrm{mL}$, indicating that eggs incubated under these conditions had a larger diameter, possibly because of changes in the egg hydration mechanism and the formation of the perivitelline space (Figure 3). Accordingly, eggs incubated in water at $\mathrm{pH}$ values of $4.43 \pm 0.13$, $5.82 \pm 0.14$, and $9.57 \pm 0.16$ presented with smaller diameters (Figure 3). Moreover, eggs incubated in water at a $\mathrm{pH}$ of $9.57 \pm 0.16$ were extremely fragile when the chorion was ruptured after manipulation; however, this finding requires more detailed analysis. 
Figure 1. Duration of spermatic motility in curimba (Prochilodus lineatus) sperm diluted in water at different $\mathrm{pH}$ values.

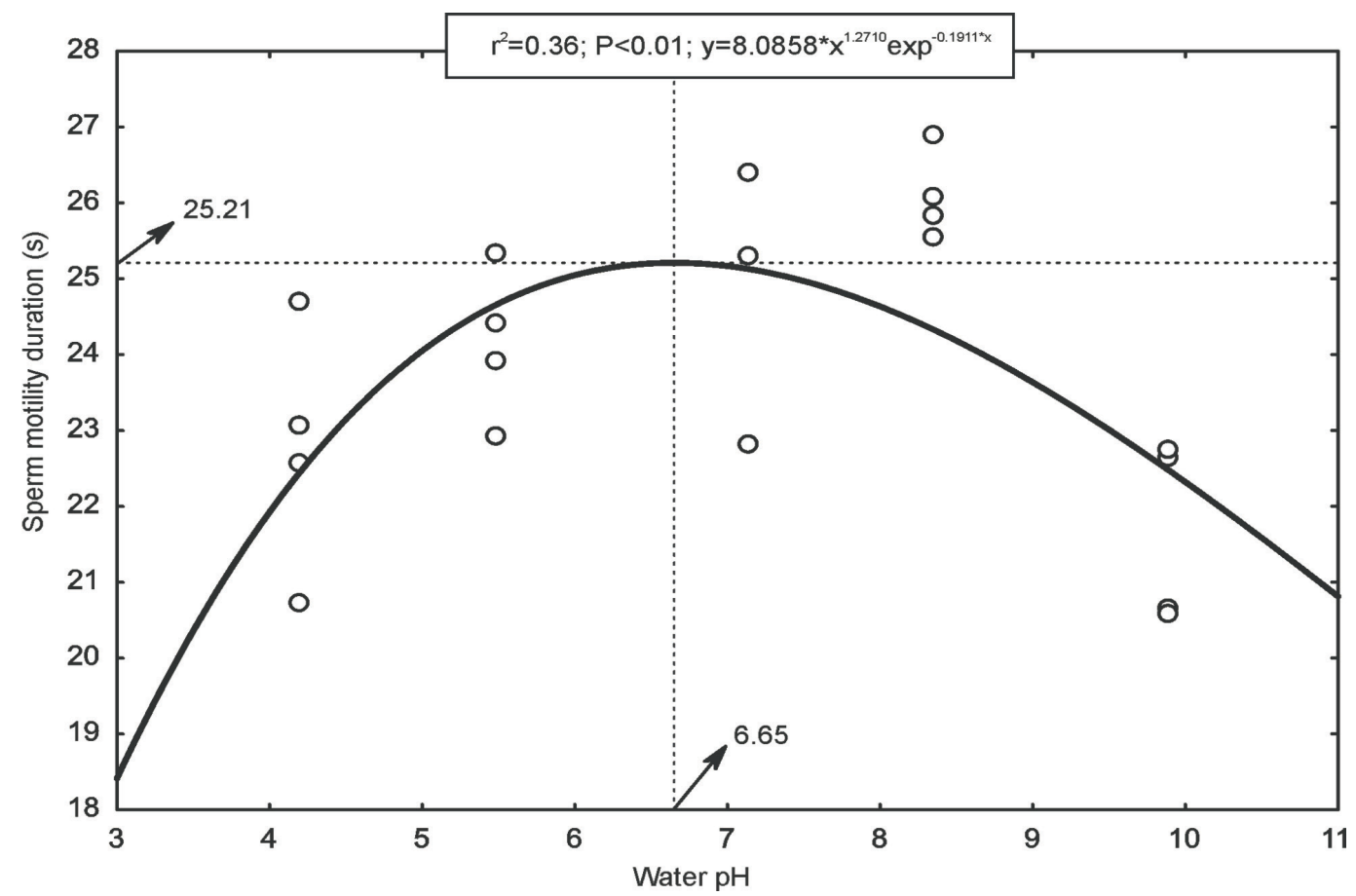

Figure 2. Artificial fertilization rates of curimba (Prochilodus lineatus) oocytes activated and incubated in water at different $\mathrm{pH}$ values.

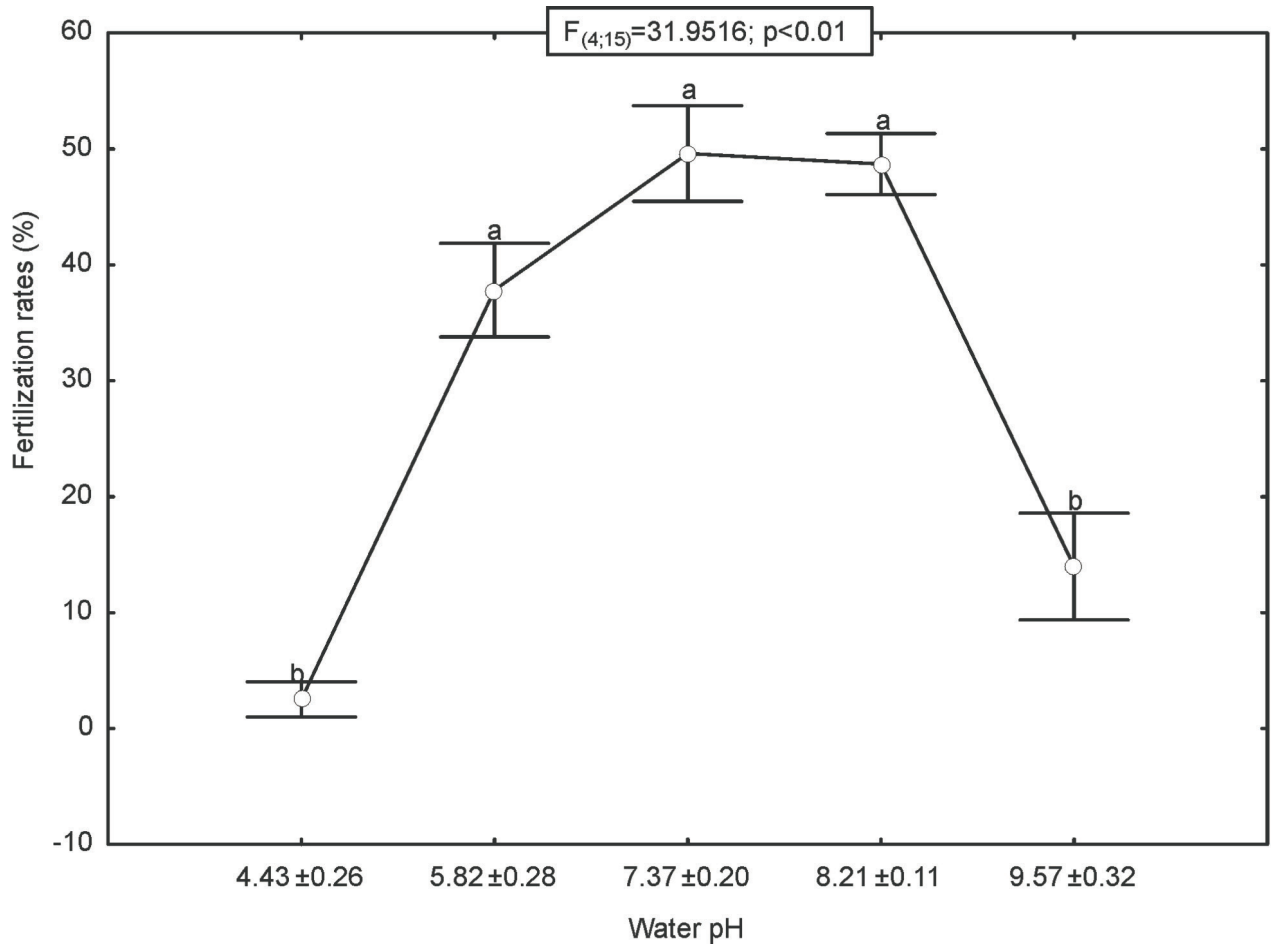


Figure 3. Number of eggs of curimba (Prochilodus lineatus) per mL. Measurements were conducted $8 \mathrm{~h}$ after the embryos were fertilized and exposed to water at different $\mathrm{pH}$ values.

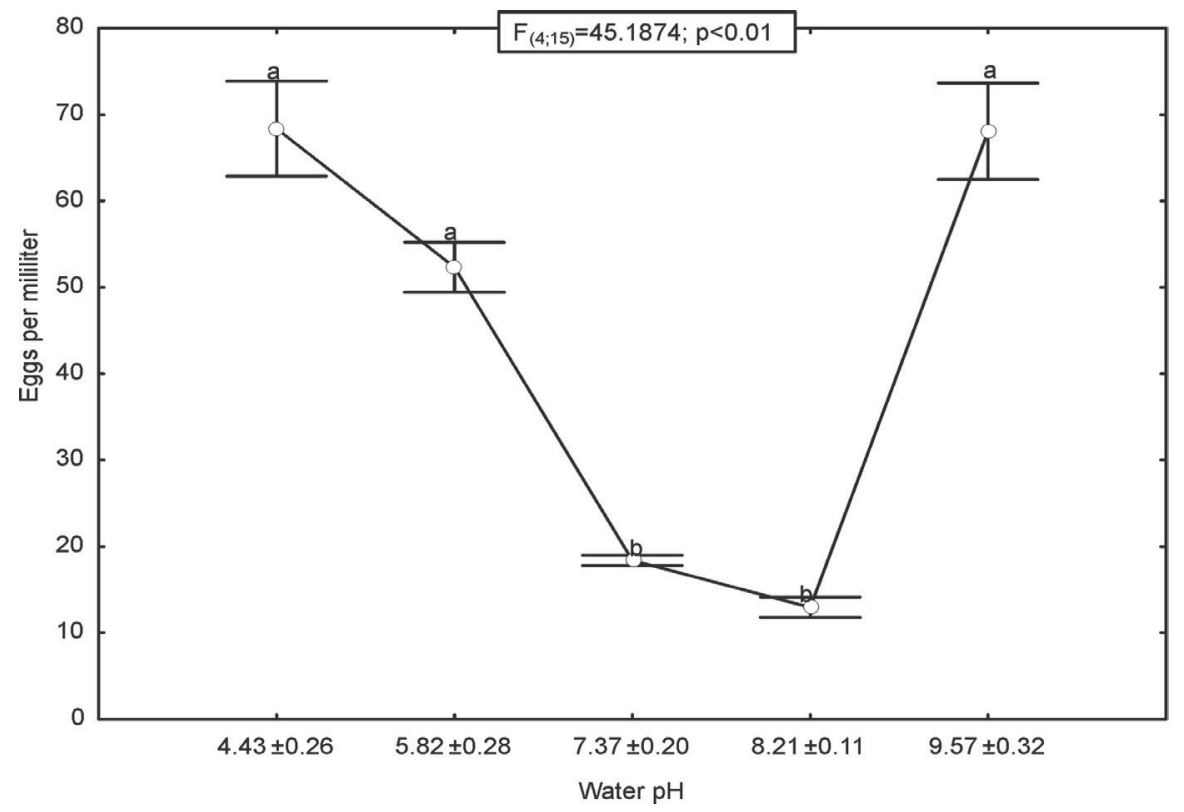

Eggs incubated in water at a $\mathrm{pH}$ of $7.37 \pm 0.10$ showed the highest hatching rates $(13.03 \pm 3.49 \%$; $\mathrm{P}<0.05$ ) (Figure 4). The mean hatching rates for other treatments were similar $(\mathrm{P}<0.05)$; however, none of the eggs incubated in water at a $\mathrm{pH}$ of 4.43 \pm 0.13 hatched; moreover, eggs incubated in water at a $\mathrm{pH}$ of $9.57 \pm 0.16$ showed a hatching rate of $0.4 \%$ (Figure 4 ).

Eggs incubated in water at a $\mathrm{pH}$ of $8.21 \pm$ 0.06 or $9.57 \pm 0.16$ produced higher numbers of normal larvae $(68.35 \pm 11.02$ and $75.97 \pm 18.04 \%$, respectively) (Figure 5).

Figure 4. Hatching rates of curimba (Prochilodus lineatus) eggs incubated in water at different $\mathrm{pH}$ values.

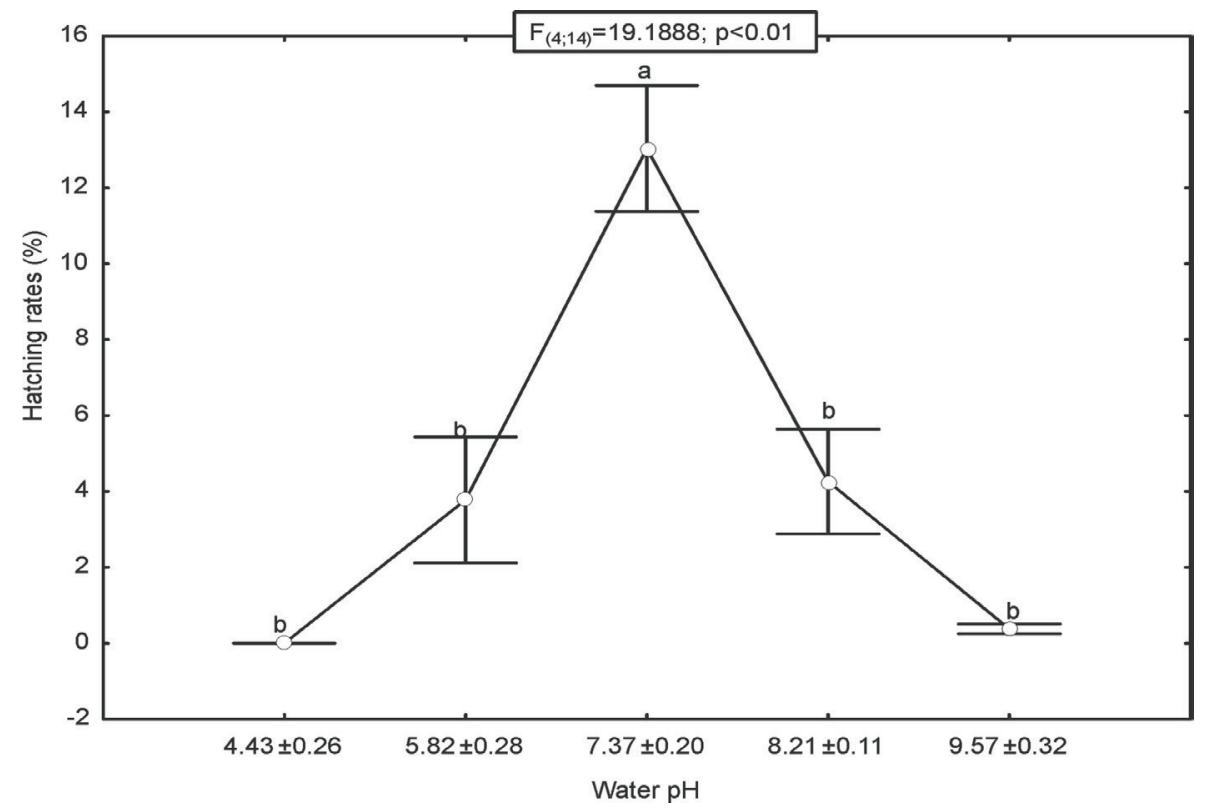


Figure 5. Percentage of normal larvae of curimba (Prochilodus lineatus) hatched from eggs fertilized and incubated in water at different $\mathrm{pH}$ values.

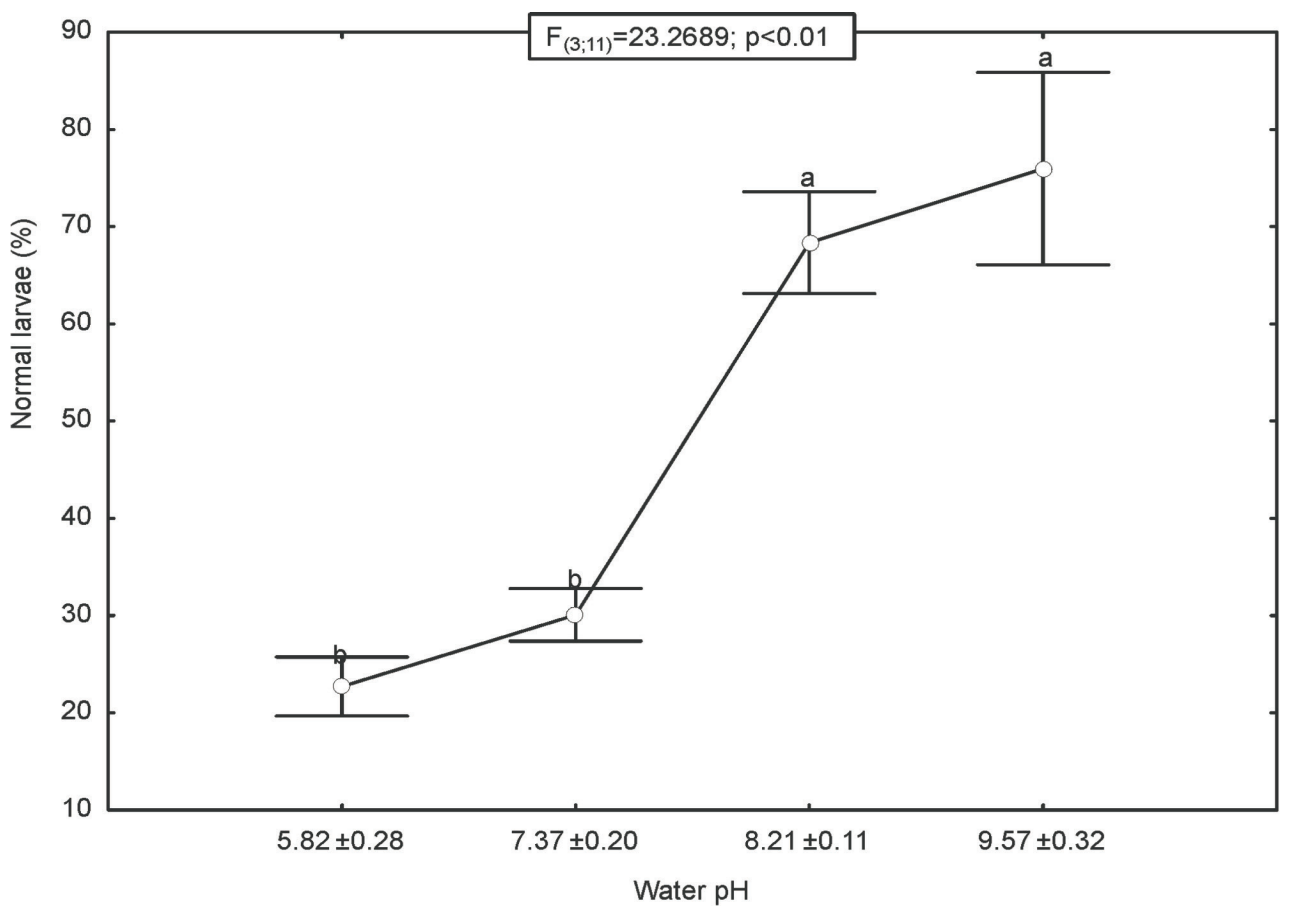

\section{Discussion}

The results of the present study regarding the movement of fresh curimba spermatozoa are in accordance with previously reported findings for individuals of this species (VIVEIROS; GODINHO, 2009; ROMAGOSA et al., 2010), suggesting that specimens from our broodstock were in good reproductive condition and produced viable gametes.

The physico-chemical parameters of the water used in the present study were within the recommended range for fish culture (OBA et al., 2009); however, data regarding the stages of fertilization, egg incubation, and larval culture of $P$. lineatus are lacking.

According to Alavi and Cosson (2005), water $\mathrm{pH}$ generally has marginal effects on spermatic motility; however, in some species, higher rates of motility have been reported when the $\mathrm{pH}$ of the sperm is similar to that of the activating solution. This is because the water used for spermatic activation directly influences the intracellular proton concentration in the spermatozoa, thereby affecting the potential of the cell membrane and interfering with spermatic motility. Our present results suggest that the maximum duration of spermatic motility occurred when semen was diluted in water at a $\mathrm{pH}$ of 6.65 ; however, further studies to elucidate the mechanisms whereby the $\mathrm{pH}$ of the activating solution influences the spermatic physiology of Neotropical fishes are required.

The aquatic medium also interferes with the fertilization and embryonic development of fishes. In Neotropical fishes, external oocyte fertilization takes place via entry of spermatozoa through the micropyle, followed by formation of the perivitelline space (a process also known as hydration) (PARRA, 2005). Similar to Brycon orbignyanus (GANECO et al., 2008), the formation of the perivitelline space in P. lineatus (FREIRE-BRASIL, 2001) occurs immediately after passage of spermatozoa through the micropyle; this process triggers the 
disarrangement of cortical alveoli, leading to water flow into the egg and inducing enlargement of the perivitelline space. During this period, cells are vulnerable to contaminants (KIME, 1999) such as heavy metals (HILBIG et al., 2008; WITECK et al., 2011), and other physical and chemical constituents of water (DEPÊCHE; BILLARD, 1994). Water $\mathrm{pH}$ has a direct influence on these processes. Gametes and embryos of most fish species are sensitive to exposure to acid waters; the degree of sensitivity depends on the ontogenetic stage (DEPECCHE; BILLARD, 1994; WOOLSEY; INGERMANN, 2004). Generally, embryos and larvae are more sensitive than juveniles and adults (DEPECCHE; BILLARD, 1994; ZANIBONI-FILHO et al., 2002). During ontogeny, water acidity seems to interfere with the exocytose of the cortical alveoli, as well with the osmotic capacity of perivitelline fluids, thereby hindering the formation of the perivitelline space, and altering the shape and resistance of eggs (DEPÊCHE; BILLARD, 1994).

Water $\mathrm{pH}$ also interferes with embryonic development, and this eventually affects the rate of egg hatching. Previous studies have shown that trout embryos incubated in very acidic waters ( $\mathrm{pH}$ of 4.55.0) rarely hatched (DEPÊCHE; BILLARD, 1994; FERREIRA, et al., 2001). FERREIRA et al. (2001) further demonstrated total mortality of Rhamdia quelen embryos incubated in water at a $\mathrm{pH}$ of 5, and total mortality after hatching of embryos incubated in water at a $\mathrm{pH}$ of 4 . This behavior may be associated with physical alterations of the chorion, such as the reduction of chorionic permeability (KUEGEL et al., 1990), or even the reduction of metabolic rates and embryonic development, because water acidity seems to delay the consumption of the yolk sac (DEPÊCHE; BILLARD, 1994) and inhibit juvenile growth (ZANIBONI-FILHO et al., 2002).

On the other hand, alkaline waters rarely occur in natural conditions, and therefore their effects have been less frequently studied (LOPES et al., 2001). Different species are more tolerant to alkaline shocks; however, Depêche and Billard
(1994) reported that $\mathrm{pH}$ values of $\sim 10$ were lethal to carp and trout.

The larvae of $P$. lineatus were previously shown to have a wide $\mathrm{pH}$ tolerance range of 4.89.2 (ZANIBONI-FILHO et al., 2009); however, the results of our present study corroborate the hypothesis that embryos of this species are sensitive to a narrower $\mathrm{pH}$ range. Our data regarding artificial fertilization and hatching rates in eggs of $P$. lineatus exposed to water at different $\mathrm{pH}$ values follow the same trend, suggesting that a higher larval productivity can be achieved when the water $\mathrm{pH}$ is $\sim 7$. This finding is associated with the more complete formation of the perivitelline space in eggs incubated in water with a $\mathrm{pH}$ of $\sim 7$. Similar to other species (DEPÊCHE; BILLARD, 1994), the tolerance of $P$. lineatus to different water $\mathrm{pH}$ values seems to decrease throughout the process of embryonic development; at $8 \mathrm{~h}$ after fertilization, the embryos tolerated a water $\mathrm{pH}$ of between 5.82 \pm 0.14 and $8.21 \pm 0.06$, whereas at hatching, they tolerated water $\mathrm{pH}$ values of $\sim 7$.

In the present study, we further showed that alkaline $\mathrm{pH}$ increases the percentage of normal larvae; however, these results may in fact be derived from the reduced number of surviving larvae in these treatments. Thus, it is possible that larvae able to survive such conditions were more resistant to the effects of water $\mathrm{pH}$, whereas more susceptible embryos perished in alkaline waters and therefore died before hatching.

In general, the results of our present study suggest that to promote gamete activation, artificial fertilization, and rearing of $P$. lineatus eggs and larvae, the water $\mathrm{pH}$ should be $\sim 7$. On the other hand, $\mathrm{pH}$ values of $<6$ or $>8$ are inappropriate for artificial breeding of this species.

Furthermore, because of the scarcity of specific information, further studies to elucidate the possible mechanisms whereby the $\mathrm{pH}$ of the activating solution influences gamete activation, oocyte fertilization, and embryonic development 
of $P$. lineatus should be conducted. These data are important for increasing the productivity of larval production units, thereby supporting the management of this fish species.

\section{References}

ALAVI, S. M. H.; COSSON, J. Sperm motility in fishes. (I) Effects of temperature and pH: a review. Cell Biology International, London, v. 29, n. 2, p. 101-110, 2005.

BLOM, E. A. One-minute live-dead sperm stain by means of Eosin-Nigrosin. Fertility and Sterility, Birmingham, v. 1, n. 2, p. 176-177, 1950.

DEPÊCHE, J.; BILLARD, R. Embriology in fish: a review. Paris: Société Française d'Ichtyologie, 1994. 122 p.

FERREIRA, A. A.; NUÑER, A. P. O.; ESQUIVEL, J. R. Influência do $\mathrm{pH}$ sobre ovos e larvas de jundiá, Rhamdia quelen (Osteichtyes, Siluriformes). Acta Scientiarum, Maringá, v. 23, n. 2, p. 77-481, 2001.

FRAYSSE, B.; MONS, R.; GARRIC, J. Development of a zebrafish 4-day embryo-larval bioassay to assess toxicity of chemicals. Ecotoxicology and Environmental Safety, Orlando, v. 63, n. 2, p. 253-267, 2006.

FREIRE-BRASIL, D. Análise estruturas e ultraestrutural da maturação final do ovócito, fertilização e primeira clivagem em curimbatá, Procholodus lineatus Valenciennes, 1836. 2001. Tese (Doutorado em Aquicultura) - Centro de Aquicultura da Universidade Estadual Paulista Júlio de Mesquita Filho, Jaboticabal.

GANECO, L. N.; FRANCESCHINI-VICENTINI, I. B.; NAKAGUI, L. S. O. Structural analysis of fertilization in the fish. Brycon orbignyanus. Zygote, Cambridge, v. 17, n. 2, p. 93-99, 2008.

HILBIG, C. C.; BOMBARDELLI, R. A.; SANCHES, E. A.; OLIVEIRA, J. D.; BAGGIO, D. M.; SOUZA, B. E. Efeito do chumbo sobre a fertilização artificial e incubação de ovos de jundiá cinza (Rhamdia quelen). Acta Scientiarum, Animal Sciences, Maringá, v. 30, n. 2, p. 217-224, 2008.

JEZIERSKA, B.; LUGOWSKA, K.; WITESKA, M. The effects of heavy metals on embryonic development of fish (a review). Fish Physiology and Biochemistry, Amsterdam, v. 35, n. 4, p. 625-640, 2009.

JONES, J. C.; REYNOLDS, J. D. Effects of pollution on reproductive behavior of fishes, Reviews in Fish Biology and Fisheries, London, v. 7, n. 4, p. 463-491, 1997.
KIME, D. E. A strategy for assessing the effects of xenobiotics on fish reproduction. The Science of the Total Environment, Amsterdam, v. 225, n. 1-2, p. 3-11, 1999.

KIME, D. E.; NASH, J. P. Gamete viability as an indicator of reproductive endocrine disruption in fish. The Science of the Total Environment, Amsterdam, v. 233, n. 1-3, p. 123-129, 1999.

KUEGEL, B.; HOFFMANN, R. W.; FRIESS, A. Effects of low $\mathrm{pH}$ on the chorion of rainbow trout, Oncorhynchus mykiss, and brown trout, Salmo trutta f. fario. Journal Fish Biology, London, v. 37, n. 2, p. 301-310, 1990.

LAHNSTEINER, F.; MANSOUR, M.; BERGER, B. The effect of inorganic and organic pollutants on sperm motility of some freshwater teleosts. Journal of Fish Biology, London, v. 65, n. 5, p. 1283-1297, 2004.

LOPES. J. M.; SILVA. L. V. F.; BALDISSEROTTO, B. Survival and growth of silver catfish larvae exposed to different water $\mathrm{pH}$. Aquaculture International, London, v. 9 , n. 1, p. 73-80, 2001.

MENEZES, N. A.; VAZZOLER, A. E. A. M. Reproductive characteristics of characiformes. In: HAMLETT, W. C. (Ed.). Reproductive biology of south american vertebrates. New York: Springer-Verlag, 1992. p. 60-70.

MORAES, G. V.; STREIT JÚNIOR, D. P.; RIBEIRO, R. P.; SAKAGUTI, E. S.; SOUZA, E. D.; POVH, J. A. Ação de diferentes indutores reprodutivos hormonais no aparecimento de anormalidades morfofógicas em espermatozóides de piavuçu (Leoporinus macrocephalus), curimbatá (Prochilodus lineatus) e carpa comum (Cyprinus carpio). Boletim do Instituto de Pesca, São Paulo, v. 30, n. 2, p. 109-116, 2004.

NAKATANI, K.; AGOSTINHO, A. A.; BAUMGARTNER, G.; BIALETZKI, A.; SANCHES, P. V.; MAKRAKIS, M. C.; PAVANELLI, C. S. Ovos e larvas de peixes de água doce. Maringá: Eduem, 2001. $378 \mathrm{p}$.

NINHAUS-SILVEIRA, A.; FORESTI, F.; AZEVEDO, A. Structural and ultrastructural analysis of embryonic development of Prochilodus lineatus (Valenciennes, 1836) (Characiforme; Prochilodontidae). Zygote, Cambridge, v. 9, n. 14, p. 217-229, 2006.

NOVAES, J. L. C.; CARVALHO, E. D. Recursos pesqueiros oriundos da pesca artesanal no reservatório de Jurumirim, Rio Paranpanema, Alto Paraná, Brasil. Boletim do Instituto de Pesca, São Paulo, v. 35, n. 4, p. 553-565, 2009. 
OBA, E. T.; MARIANO, W. S.; SANTOS, L. R. B. Estresse em peixes cultivados: agravantes e atenuantes para o manejo rentável. In: TAVARES-DIAS, M. (Ed.). Manejo e sanidade de peixes em cultivo. Amapá: Embrapa, 2009. p. 226-247.

PARRA, M. A. L. Mecanismos celulares de la reproduccíon de los peces In: DAZA, P. V.; PARRA, M. A.; OCHOA, A. I. S. (Ed.). Reproduccíon de los peces en el trópico. Bogotá: Incoder, 2005. p. 11-22.

PEREIRA, L. P. F.; MERCANTE, C. T. J. A Amônia nos sistemas de criação de peixes e seus efeitos sobre a qualidade da água. Uma revisão. Boletim do Instituto de Pesca, São Paulo, v. 31, n. 1, p. 81-88, 2005.

PEREIRA, B. L.; CINTRA, B.; FONSECA, V. E.; LUNA, H. S. Índice gonadossomático como indicador do período reprodutivo de Prochilodus lineatus (Pisces, Characidae) nos rios aquidauana e miranda. In: SIMPÓSIO SOBRE RECURSOS NATURAIS E SÓCIO-ECONÔMICOS DO PANTANAL, 2004, Corumbá. Anais... Corumbá: [s.n.], 2004. Resumo.

PEREIRA, G. J. M.; MURGAS, L. D. S.; SILVA, J. M. A.; MILIORINI, A. B.; LOGATO, P. V. R.; LIMA, D. Indução da desova de curimba (Prochilodus lineatus) utilizando ECG e BHC1. Revista Ceres, Viçosa, MG, v. 56, n. 2, p. 156-160, 2009.

QUINN, G. P.; KEOUGH, M. J. Experimental design and data analysis for biologists. New York: Cambridge University Press, 2002. 537 p.

ROMAGOSA, E.; SOUZA, B. E.; SANCHES, E. A.; BAGGIO, D. M.; BOMBARDELLI, R. A. Sperm motility of Prochilodus lineatus in relation to dilution rate and temperature of the activating medium. Journal Applied Ichthyology, Hamburg, v. 26, n. 5, p. 678-681, 2010.

SANCHES, E. A.; BOMBARDELLI, R. A.; BAGGIO, D. M.; SOUZA, B. E. Dose inseminante para fertilização artificial de ovócitos de dourado Revista Brasileira de Zootecnia, Viçosa, MG, v. 38, n. 11, p. 2091-2098, 2009.
SANCHES, E. A.; MARCOS, R. M.; BAGGIO, D. M.; TESSARO, L.; BALEN, R. E.; BOMBARDELLI, R. A. Estimativa da concentração espermática do sêmen de peixe pelo método espermatócrito. Revista Brasileira de Zootecnia, Viçosa, MG, v. 40, n. 6, p. 1163-1167, 2011.

SOUZA, B. E. Fertilização artificial de curimbatá Prochilodus lineatus. 2007. Dissertação (Mestrado em Aquicultura) - Universidade Estadual Paulista Júlio de Mesquita Filho, Jaboticabal.

STATSOFT. Inc. Statistica (Data analysis software system). Version 7. 0. Tulsa, USA, 2005.

TOMITA, R. Y.; BEYRUTH, Z. Toxicologia de agrotóxicos em ambiente aquático. $O$ Biológico, São Paulo, v. 64, n. 2, p. 135-142, 2002.

VIVEIROS, A. T. M.; GODINHO, H. P. Sperm quality and cryopreservation of Brazilian freshwater fish species: a review. Fish Physiology and Biochemistry, Amsterdam, v. 35, n. 1, p. 137-150, 2009.

WITECK, L.; BOMBARDELLI, R. A.; SANCHES, E. A.; OLIVEIRA, J. D.; BAGGIO, D. M.; SOUZA, B. E. Motilidade espermática, fertilização dos ovócitos e eclosão dos ovos de jundiá em água contaminada por cádmio. Revista Brasileira de Zootecnia, Viçosa, MG, v. 40, n. 3, p. 477-481, 2011.

WOOLSEY, J.; INGERMANN, R. L. Acquisition of the potencial for sperm motility in steelhead (Oncorhynchus mykiss): effect of $\mathrm{pH}$ on dynein ATPase. Fish Physiology and Biochemistry, Amsterdam, v. 29, n. 1, p. 47-56, 2004.

WOYNAROVICH, E.; HORVÁTH, L. The artificial propagation of warm:- water fin fishes - a manual for extension. Brasíla: Escopo, Translation by Chama V. L. M. FAO/CODEVASF/CNPq, 1983. 220 p.

ZANIBONI-FILHO, E.; NUÑER, A. P. O.; REYNALTETATAJE, R. A.; SERAFINI, R. L. Survival of Prochilodus lineatus (Valenciennes) fingerlings exposed to acute $\mathrm{pH}$ changes. Acta Scientiarum, Maringá, v. 24, n. 4, p. $917-$ $920,2002$.

Water $\mathrm{pH}$ and Prochilodus lineatus larvae survival. Fish Physiology and Biochemistry, Amsterdam, v. 35, n. 1, p. 151-155, 2009. 